Kim Cragin*

\title{
THE GLOBAL ISIS THREAT IN HISTORICAL CONTEXT
}

DOI: $10.20542 / 2307-1494-2017-1-77-90$

Keywords: ISIS, ISIS provinces, ISIS affiliates, foreign fighters, al-Qaeda, Middle East and North Africa, Europe, North America, South Asia, Southeast Asia, Abu Musab al-Suri, Abu Bakr Naji, external operations, logistics, recruitment, leadership, training

Abstract: Despite successful military operations against ISIS core in Mosul and Raqqah, the global threat posed by ISIS "provinces" beyond Syria and Iraq, but also by other groups that declared loyalty to ISIS and foreign fighters is unlikely to diminish in the near term. ISIS provinces already have been able to establish an operational tempo that exceeds the historical precedent established by al-Qaeda. Other ISIS cells and affiliates worldwide have sustained a campaign against security forces and civilian targets. Much of their success can be attributed to the effectiveness of ISIS foreign fighters who not only participate in ISIS' external operations, but have also taken on the role of logisticians and recruiters. Finally, foreign fighters linked to ISIS are likely to follow historical patterns that characterize foreign fighters and try to provide local recruits with increased guerrilla warfare and terrorist skills as well as establish new militant groups back home.

Ключевые ИГИЛ, провинции ИГИЛ, филиалы ИГИЛ, иностранные боевики, аль-Каида, слова: Ближний Восток и Северная Африка, Европа, Северная Америка, Южная Азия, Юго-Восточная Азия, Абу Мусаб ас-Сури, Абу Бакр Наджи, зарубежные операции, логистика, вербовка, руководство, подготовка и обучение

Аннотация: Несмотря на успешные военные операции против ядра ИГИЛ в Мосуле и Ракке, глобальная угроза, которую представляют так называемые провинции ИГИЛ за пределами Сирии и Ирака, а также другие группировки, провозгласившие лояльность ИГИЛ, и иностранные боевики, в ближайшие годы вряд ли пойдет на спад. Интенсивность вооруженных операций, которые ведут «провинции» ИГИЛ за пределами ее основного территориального ядра, уже превысила соответствующий исторический рекорд фрилиалов аль-Каиды. Другие ячейки ИГИЛ и связанные или вдохновленные им группировки по всему миру также продолжают вести активные вооруженные действия как против сил безопасности, так и против гражданских целей. Своей эфффективностью эти действия в значительной мере обязаны иностранным боевикам-террористам ИГИЛ, которые не только участвуют в операциях ИГИЛ за пределами Сирии и Ирака, но и

\footnotetext{
* Kim Cragin is a senior research fellow for terrorism at the National Defense University's Institute for National Strategic Studies. The opinions expressed here represent her own views and are not those of the National Defense University, the Department of Defense, or the U.S. government. Special thanks to Kira McFadden and Alexander Pinto, interns at the National Defense University, for their research support on this article.
} 
выполняют функции финансово-технического обеспечения и ведут вербовочную деятельность. Наконец, высока вероятность того, что связанные с ИГИЛ иностранные боевики-террористы пойдут по пути своих предшественников и, по возвращении домой, попытаются наладить обучение местных рекрутов навыкам ведения партизанской войны и террористических операций, а также основать новые вооруженные группировки.

\section{Introduction}

This article argues that eliminating Islamic State in Iraq and Syria (ISIS) strongholds in Mosul and Raqqah will not remove its global threat. Evidence suggests that ISIS will continue to threaten populations not only in the Middle East and North Africa, but also in North America, Europe, South and Southeast Asia, as well as Australia. These threats may take the form of attacks conducted by local insurgents loyal to ISIS, ISIS-directed external operations by foreign fighters, or even attacks by "homegrown" terrorists inspired by ISIS recruiters. The threat posed by ISIS has metastasized so that it now exceeds the impact of al-Qaeda's network in the past decade. Thus, eliminating its strongholds or reducing its control over territory within Syria and Iraq will not be sufficient to secure defeat.

To do this, this article combines a discussion of ISIS' global strategy, as articulated by its leaders and ideologues, with a review of ISIS attacks over the past three years. This review also includes an assessment of the threat posed by ISIS foreign fighters and, equally important, foreign fighter returnees. The findings are presented in comparison with the historical threats posed by al-Qaeda and al-Qaeda foreign fighters in other recent conflicts. The key findings include the following:

- ISIS has been able to expand its appeal to supporters outside al-Qaeda's traditional sphere of influence: of the 48 militant groups who have joined ISIS outside the borders of Syria and Iraq, only a third were once part of al-Qaeda's network.

- ISIS fighters outside Syria and Iraq are more active than al-Qaeda affiliates from the recent past: 227 attacks were conducted by ISIS between January 2014 and December 2016, as compared to 119 for al-Qaeda outside Iraq between January 2008 and December 2010.

- Foreign fighters play essential roles in ISIS' global campaign: they are responsible for $35 \%$ of attacks against the West, $36 \%$ of those in the Middle East and North Africa, and $20 \%$ of ISIS attacks in Asia.

\section{Definitions}

This article uses the term "terrorists" to refer to individuals who conduct attacks against civilian populations to achieve a political objective. "Insurgents", by comparison, tend to engage in guerrilla warfare. Guerrilla warfare differs somewhat from a terrorist campaign. The operatives attempt to gain control over people and territory and, 
therefore, often engage in skirmishes with opposing security forces. ${ }^{1}$ Sometimes terrorists and insurgents also engage in external operations, or attacks against targets outside their primary areas of operations. ISIS fighters have engaged in guerrilla warfare, external operations, as well as terrorist campaigns over the past three years.

This article also utilizes the term "foreign fighters" to identify individuals who travel abroad to fight in a local insurgency or participate in a terrorist campaign. "Foreign fighter returnees" are individuals who fight abroad and then return to their country of origin. Sometimes these individuals reintegrate peacefully but sometimes they reengage in violence in upon their return home. This reengagement is referred to as "recidivism" here. In contrast to foreign fighters, "homegrown terrorists" have not travelled abroad to fight, but rather are recruited locally in-person or via social media. They also may simply have become inspired to act on their own without interactions with a specific recruiter. Either way, they conduct attacks locally without having been trained by a foreign terrorist organization. ${ }^{3}$

\section{Data Sources and Methods}

The findings in this article draw on multiple data sources and methods. First, the article includes a basic analysis of the pattern of attacks conducted by ISIS operatives outside Syria and Iraq. The analysis utilizes a dataset of ISIS attacks built by the author and interns at the National Defense University (NDU) as part of a series of papers on the threat posed by ISIS foreign fighters. ${ }^{4}$ Various media sources inform the dataset, including reports in the "New York Times", "Time Magazine", "Christian Science Monitor", BBC News, "al-Monitor" (Washington DC), "al-Arabi al-Jadeed" (London), "Le Monde" (Paris), "al-Ahram" (Cairo), "al-Arabiyah" (Dubai), "Utusan” (Kuala Lumpur), and "The Straits Times" (Singapore). The dataset was also built using non-traditional media, such as YouTube and Twitter, especially as researchers tried to identify those attacks perpetrated by foreign fighters. We validated the dataset further with existing datasets of terrorism incidents, including those published by the "Jane's Terrorism and Security Monitor" and START project (National Consortium for the Study of Terrorism and Responses to Terrorism) at the University of Maryland.

Second, the findings are also informed by ISIS documents published on associated websites or through Twitter accounts and other publicly available documents written by well-known strategists or ideologues. These documents include, for example, the book entitled "Management of Savagery" written by ideologue Abu Bakr Naji, ${ }^{5}$ Abu Muhammad al-Adnani's "This is the Promise of Allah" that announced the creation of the ISIS caliphate, ${ }^{6}$ and "A Call to Hijrah" and other articles released in "Dabiq", the English-language magazine produced by ISIS. ${ }^{7}$ These documents provide unique insight into not only ISIS strategy, but also how ISIS leaders expect to accomplish their objectives.

Third, and finally, the research and analysis in this article also incorporate findings from interviews with former foreign fighters conducted by investigative journalists and published in Arabic or English-language newspapers. Additionally, field research was 
conducted by the author and other NDU research staff in Algeria, Bosnia and Indonesia in the fall of 2016. As part of this field research, 27 interviews were conducted with security officials, civil society representatives, journalists and former foreign fighters. While the detailed findings from these interviews were released in separate academic articles, referenced previously, they also inform the analysis contained in this article.

\section{ISIS' Global Strategy}

ISIS' global strategy is best understood in the context of a series of ongoing debates within the wider Salafi movement. Salafism is a conservative ideological strain within Sunni Islam. Salafis believe that Muslims should adhere to religious practices from the time of the Prophet and that innovations, or religious liberalism, should be rejected. Within Salafism, some individuals focus on achieving a religious revival, sometimes referred to as an internal jihad or a spiritual struggle within each individual Muslim. Others have political objectives. They believe that governments in majority Muslim countries should implement their conservative interpretation of Islamic law (shariah). Importantly, these individuals reject democracy because Muslim legislators, by enacting new laws, essentially place themselves in a position to improve upon shariah law. ${ }^{8}$

Within the category of Salafis who pursue political objectives, some argue that violent revolutions represent the only way to achieve their goals. These violent revolutions sometimes are referred to as a political, or external, jihad. A number of wellknown militant groups over the years, arguably, have made this argument. They include ISIS and al-Qaeda, the Egyptian Islamic Group (EIJ), as well as the Armed Islamic Group (GIA) that fought a civil war in Algeria in the mid-1990s. However, within this category of militants - sometimes referred to as violent Salafi jihadists - significant disagreement also exists. Much of this disagreement centers on priorities and methods or, essentially, the strategies pursued by each militant organization. ${ }^{9}$

One of the most well-known debates amongst violent Salafi jihadists is whether to prioritize campaigns aimed at expelling foreign security forces from Muslim lands (defensive jihad) or overthrowing "corrupt" Muslim governments (offensive jihad). This debate, in many ways, has been personified over the years by, on the one side, Palestinian ideologue Abdullah Azzam who argued in 1984 that it was an individual duty for all Muslims to assist others in expelling foreign occupiers. ${ }^{10}$ On the other side, Ayman al-Zawahiri, the current leader of al-Qaeda, argued in a 1991 treatise entitled "Bitter Harvest" that Salafi jihadists should prioritize "apostate" or corrupt Muslim regimes. ${ }^{11}$ The term "apostate", or kufr, is important in this context, because it allows Salafi jihadists to legitimize killing other Muslims. Salafi jihadists who wage concerted campaigns against Muslim civilian populations, such as al-Qaeda in Iraq (AQI) during the last decade or ISIS today, often are referred to as takfiris amongst other Muslims. ${ }^{12}$

Another well-known debate amongst violent Salafi jihadists is whether to prioritize campaigns against the near enemy versus far enemy. ${ }^{13}$ These individuals want to overthrow so-called apostate Muslim regimes, but they disagree about how best to 
achieve these objectives. Some, such as former al-Qaeda leader Osama bin Laden, have argued that the best way to do this is to diminish Western influence on Muslim governments. Without the support of the United States and other Western countries, this argument explains, these Muslim governments will be much easier to overthrow. This argument gained prominent amongst Salafi jihadists in the late 1990s and through the mid-2000s.

Beginning in 2004, however, some well-known ideologues began to argue for alternative strategies to overthrow apostate Muslim regimes. The most prominent were Abu Musa'b al-Suri, author of "Call for Global Islamic Resistance", and Abu Bakr Naji, author of "Management of Savagery". ${ }^{14}$ Both rejected as untenable Osama bin Laden's strategy of using spectacular attacks against the United States and the West to diminish their influence over Muslim governments. Both argued that violent Salafi jihadists should adopt a global campaign against so-called apostate Muslim regimes. But al-Suri and Naji disagreed on how to do this effectively.

For his part, al-Suri believed that Salafi jihadists should adopt a limited campaign of "open confrontation" against a few Muslim regimes and then, in other locations, execute discrete attacks through disaggregated leaderless resistance. ${ }^{15}$ Al-Suri also cautioned against the method of wide-scale attacks against other Muslims, including Shi'a populations. ${ }^{16} \mathrm{Naji}$, in contrast, rejected this approach. He argued that civil war within Muslim countries was a necessary precursor to a political revolution. And, in pursuing civil war, Naji believed that Salafi jihadists should establish territorial control over small areas within each Muslim countries, implement shariah as they interpreted it, and defend this territory against all opponents, brutally if necessary. ${ }^{17}$

These internal debates, as personified initially by Azzam and al-Zawahiri, and now by al-Suri and Naji, explain, in part, ISIS' global strategy and its brutal tactics on the battlefields. ISIS, in many ways, represents a rejection of al-Qaeda and its perceived incrementalism amongst violent Salafi jihadists. It is pursuing a full-scale global strategy aimed not so much at Western countries, but at majority Muslim governments. That said, any countries or institutions worldwide viewed as threatening its control over territories are being punished through brutal tactics, either through external operations, or within its perceived territory (e. g. beheadings). The following sections explore the manifestation of this campaign further through its pattern of attacks and use of foreign fighters.

\section{Patterns of Attacks}

In many ways, Abu Bakr al-Baghdadi and other ISIS leaders have followed the strategy outlined by Abu Bakr Naji in his 2004 "Management of Savagery". That is, ISIS leaders have focused on establishing administrative control over parts of Iraq and Syria. They declared an Islamic caliphate in June 2014 in the areas under their control prior to the complete overthrow of existing state structures. ${ }^{18}$ Beyond Syria and Iraq, over the past three years ISIS also has established - or at least acknowledged - 25 provinces in 11 countries. Among these provinces are Wilayat al-Barqa, Tripoli, and Fizzan in Libya, 
Wilayat Sinai (Egypt), Wilayat Sana'a, Aden, Shabwah, Lahij in Yemen, Wilayat Philippines, Wilayat Khorasan (Afghanistan and Pakistan) and Wilayat Gharb Ifriqiyyah (West Africa). ${ }^{19}$ Figure 1, below, depicts ISIS' global presence, according to its declared provinces.

Figure 1. 25 ISIS Provinces in 11 Countries (March 2017)

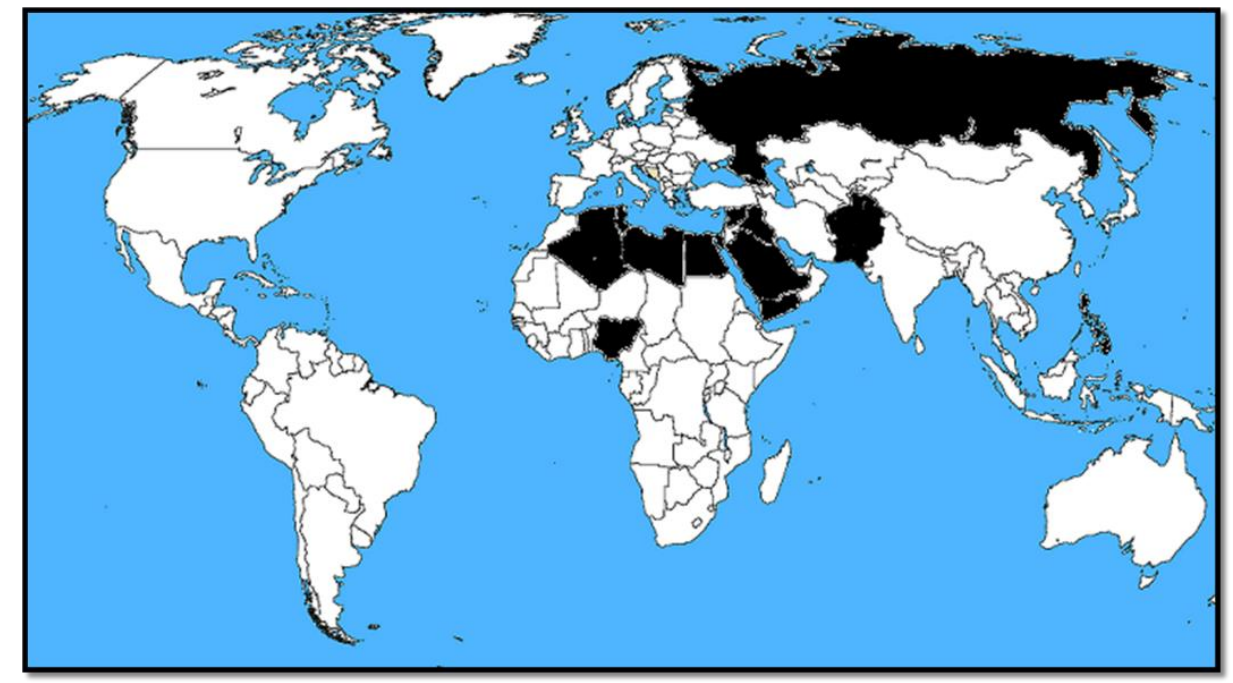

Of course, many of these so-called provinces had ongoing insurgencies prior to the rise of ISIS in Syria and Iraq. In the Philippines, for example, some members of the Abu Sayyaf Group switched their allegiance from al-Qaeda to form Wilayat Philippines. This defection also occurred in Egypt: members of the "Ansar Beit al-Maqdis" eventually formed ISIS' Sinai province, Wilayat Sinai. ${ }^{20}$ Questions remain, therefore, on the extent to which ISIS represents a truly global threat and whether or not it has expanded this threat beyond merely accepting pledges of loyalty from insurgents who were already fighting for al-Qaeda.

Part of the answer can be found in the number of "defections" from al-Qaeda's network to ISIS after the June 2014 declaration of a caliphate by ISIS spokesman al-Adnani. As mentioned previously, as of March 2017, ISIS had declared 25 provinces with local affiliates essentially "in charge" of each province. In addition to these provinces, 23 militant groups also had announced their loyalty to ISIS leader Abu Bakr al-Baghdadi. Of the total of 48 groups, a third (16) were once part of al-Qaeda's network. This suggests that ISIS has been able to expand its appeal to supporters outside al-Qaeda's traditional sphere of influence. ${ }^{21}$

Beyond defections, however, the pattern of attacks by ISIS fighters outside Syria and Iraq also can help explain the nature and extent of ISIS' global threat. Figure 2, below, displays the distribution of attacks by ISIS fighters outside Syria and Iraq by month. The dataset contains 227 attacks and disrupted attacks by ISIS fighters and operatives between January 2014 and December 2016. Comparatively speaking, al-Qaeda fighters conducted 210 attacks and disrupted attacks outside of Iraq between 
January 2008 and December 2010.22 This number includes 91 attacks by al-Shabaab fighters in Somalia. Al-Shabaab was not officially accepted into al-Qaeda's network until February 2012. ${ }^{23}$ So, if we remove attacks by al-Shabaab between 2008 and 2010, alQaeda's global network conducted 119 attacks and disrupted attacks, roughly 52\% of those conducted by ISIS during a similar three year period. ${ }^{24}$ This suggests that ISIS fighters outside the borders of Syria and Iraq also are significantly more active than alQaeda affiliates from the recent past.

Figure 2. ISIS attacks outside Syria and Iraq (March 2017)

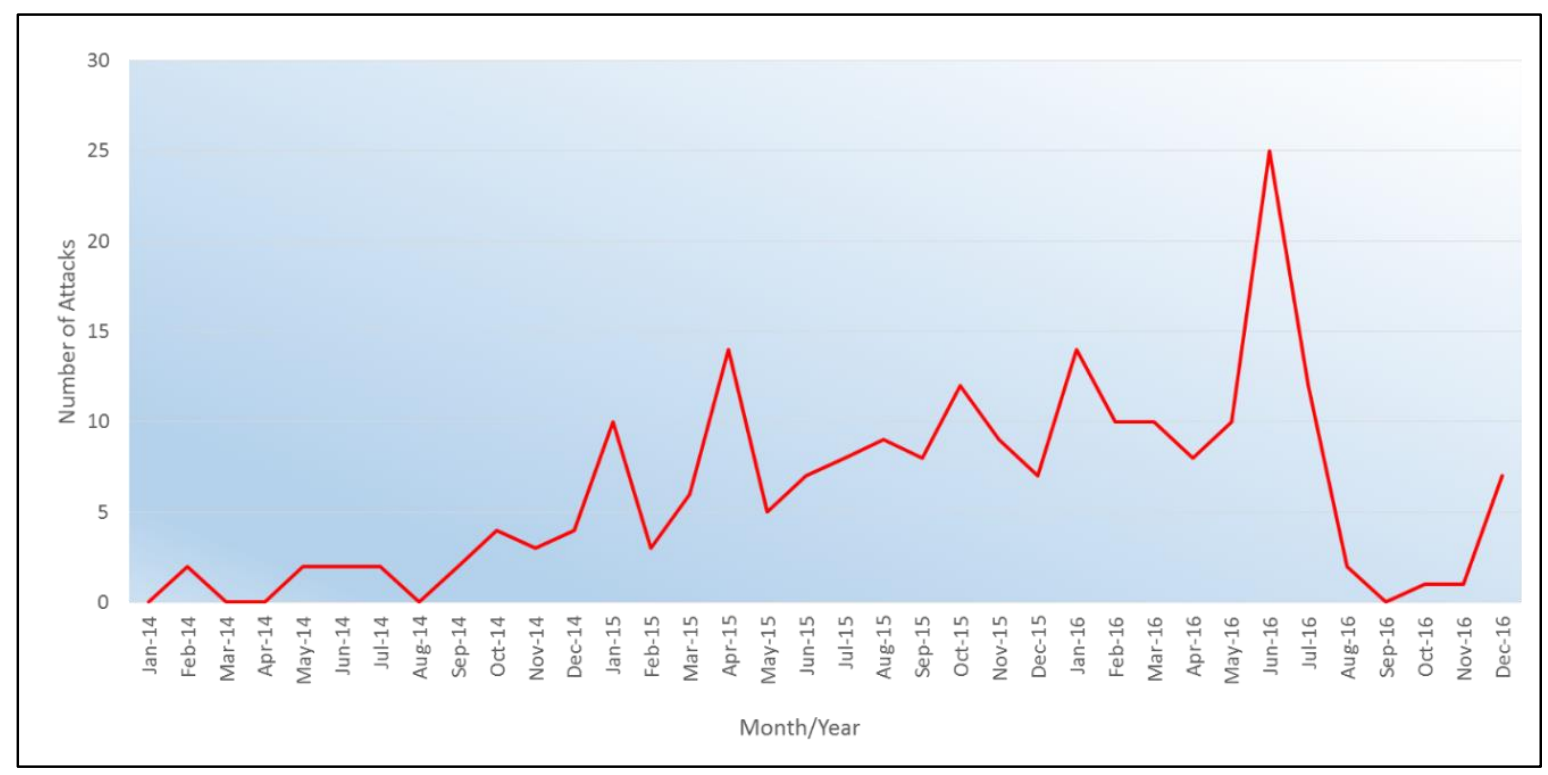

Interestingly, the dataset of ISIS attacks also reveals that insurgents in ISIS' provinces are responsible for $56 \%$ of the total number of attacks between January 2014 and December 2016. Much of the attacks in the provinces have targeted police and other security forces. The purpose, in many ways, has been to establish and maintain control over "administrations of savagery" across the Muslim world. However, ISIS fighters also have initiated a widespread campaign in these provinces against civilian Muslims that they view as apostates, namely Shia Muslims and Sunni Muslims that opposed ISIS ideologically. ISIS has also attacked non-Muslim civilian populations. The following list provides some examples of the type of attacks by ISIS fighters in its 25 provinces:

October 2015. ISIS-Sinai claimed responsibility for an attack against a Russian passenger jet that was departing the Sinai with vacationers. The attack killed all 224 people on board.

January 2016. ISIS claimed responsibility for an attack on a Shia mosque in al-Ahsa, Saudi Arabia, which killed at least four people and injured approximately 30 .

June 2016. ISIS-Sana'a claimed responsibility for a series of car bombings in the capital that killed approximately 30 individuals. 
February 2017. ISIS-Khorasan claimed responsibility for a series of bombings against Afghan police in Jalalabad that killed five and wounded unspecified others.

Moreover, within these provinces, foreign fighters and returnees have played a relatively important role in sustaining ISIS' global campaign. They have been responsible for more than a quarter (28\%) of all of the attacks conducted within the ISIS provinces. That is, foreign fighters have either been an operative, or a logistician or a direct planner in $28 \%$ of these attacks. These numbers are significant. Again, comparatively speaking, foreign fighters were responsible of $90 \%$ of the suicide attacks in Iraq between 2003 and $2010,{ }^{25}$ but only an estimated $20 \%$ of all anti-Coalition attacks. ${ }^{26}$ This suggests that foreign fighters have had a more significant role in executing ISIS' global agenda, at least amongst its provinces, than they did in the past for al-Qaeda.

Figure 3. ISIS attacks by foreign fighters, regionally (March 2017)

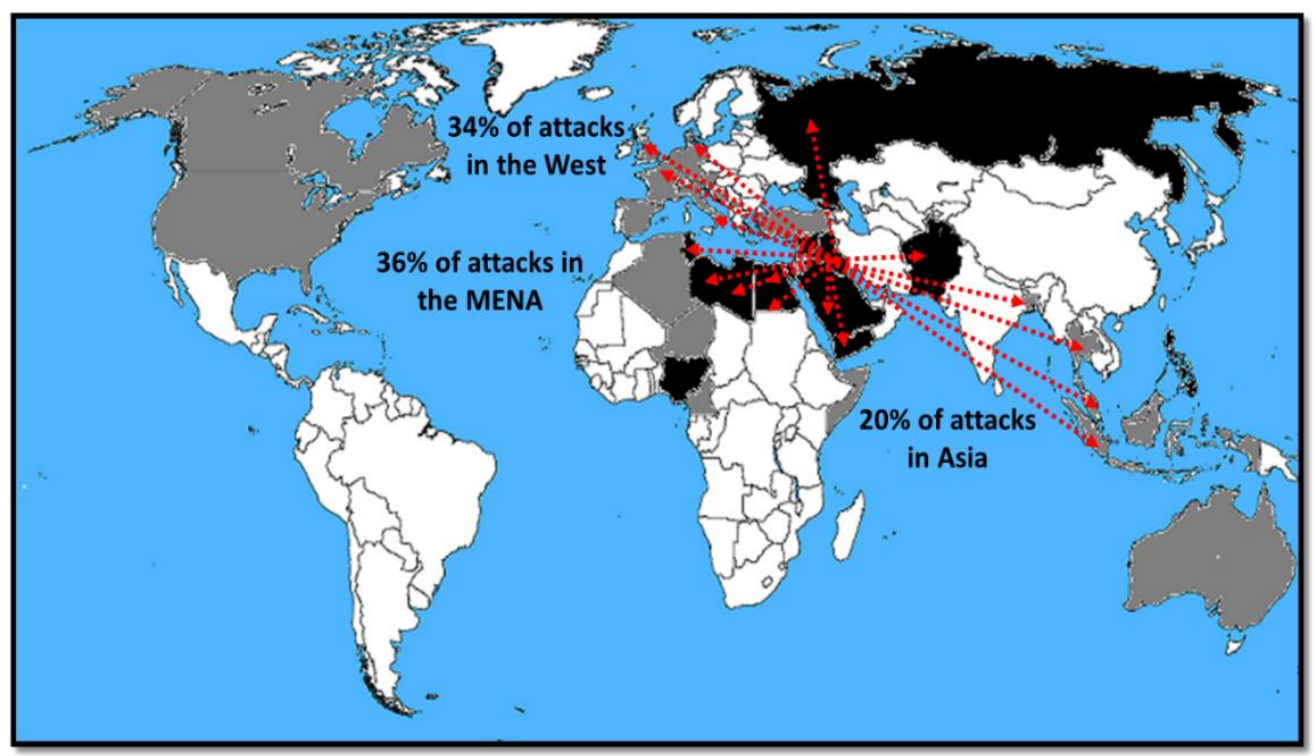

In this context, it would be easy to dismiss ISIS as primarily a threat to the Middle East and North Africa (MENA). After all, a majority of the ISIS provinces are in the MENA region and the largest populations of foreign fighters in Syria and Iraq reportedly come from Tunisia, Saudi Arabia, Russia, Jordan and Turkey, respectively. ${ }^{27}$ But, significantly, the data suggest otherwise. $44 \%$ of the total number of ISIS attacks in our dataset occurred outside the provinces. While some of these attacks were directed against security forces, most targeted civilian populations. The following list provides some examples of the type of attacks by ISIS fighters outside its provinces:

September 2014. An 18-year-old ISIS sympathizer was killed after stabbing two officers outside a police station in Melbourne, Australia.

September 2015. ISIS claimed responsibility for killing an Italian aid worker in Bangladesh. 
January 2016. A suicide bomber set off an explosion in Istanbul, killing 10 people and wounding at least 15 others.

July 2016. A man drove a truck into pedestrians on a crowded beach promenade in Nice, France. The attacked killed 84 and wounded 303.

Like with the attacks in the provinces, foreign fighters have also played an important role in the execution of ISIS' strategy beyond these territories: they are responsible for $34 \%$ of attacks in Europe and $37 \%$ of all attacks outside the ISIS provinces. Figure 3, below, depicts the extent of ISIS' influence geographically. It illustrates the distribution of attacks by ISIS foreign fighters according to region. It is followed by Figure 4 that further illustrates the important roles played by foreign fighters and foreign fighter returnees in ISIS attacks worldwide. It depicts the proportion of ISIS attacks with foreign fighter involvement by month between January 2014 and December 2016.

Figure 4. ISIS Attacks by Foreign Fighters, Monthly (March 2017)

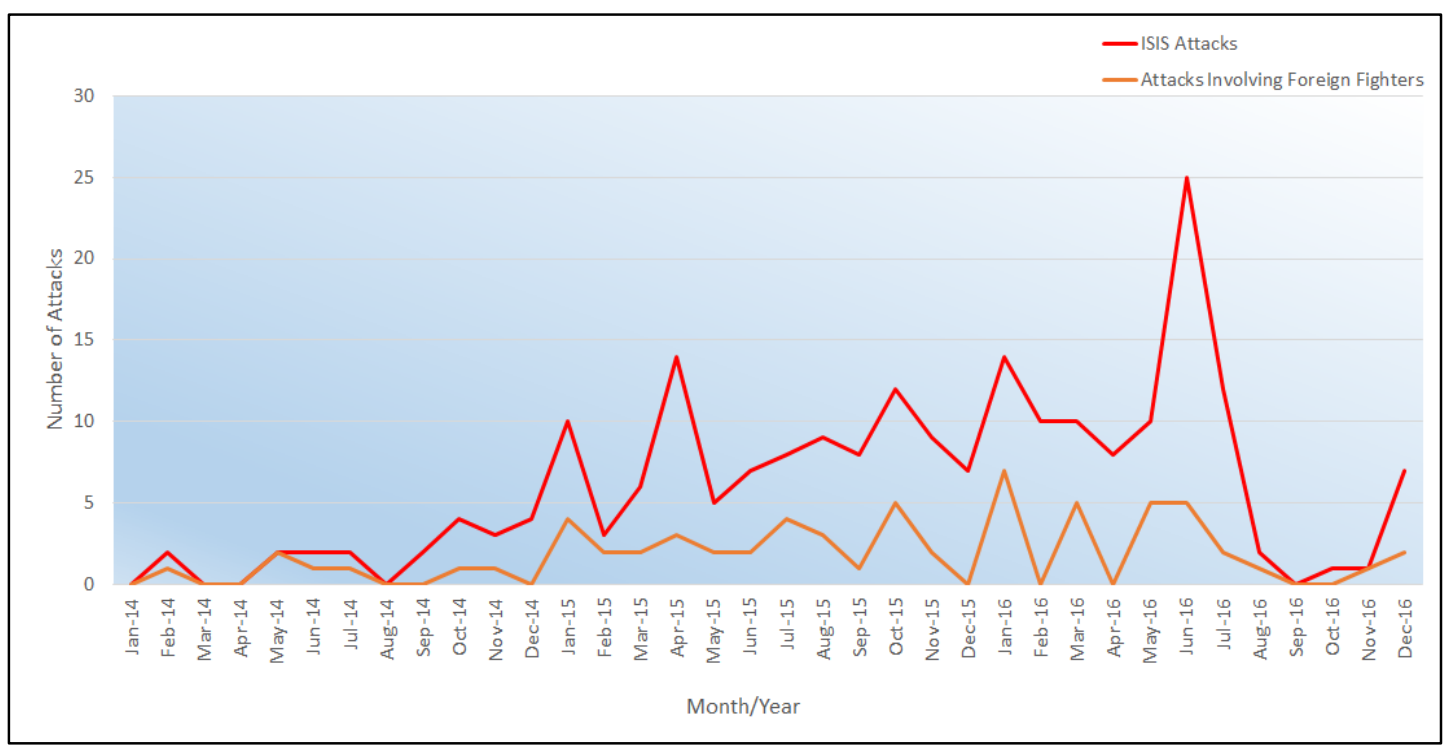

This basic overview of the pattern of attacks by ISIS and ISIS foreign fighters demonstrates that it represents a global threat. This threat clearly exceeds levels presented by al-Qaeda in the recent past. Moreover, the findings also suggest that foreign fighters play a central role in elevating the ISIS threat worldwide. In this context, it is useful to further explore the role played by foreign fighters in ISIS attacks worldwide and compare this to the historical experiences of foreign fighters and foreign fighter returnees in past conflicts, such Afghanistan (1984-1992), Bosnia (1992-1995), Algeria (1992-1998), Indonesia (2001-2006), and Iraq (2004-2009). 


\section{Foreign Fighters}

According to newspaper accounts, ISIS leaders gathered in Tabqah, Syria, on 4 November 2015 to discuss how they could increase the number and effectiveness of external operations in Europe, including Italy, Belgium, France and the United Kingdom. They reportedly intended to use foreign fighter returnees to conduct these attacks. ${ }^{28}$ Indeed, just a few days later, on 13 November 2015, nine ISIS operatives executed a series of attacks in Paris, killing 129 individuals. Of these nine operatives, seven were foreign fighter returnees sent home by ISIS to participate in the attacks. So in many ways the Paris attacks exemplify the prospect and utility of foreign fighters to ISIS leaders. ${ }^{29}$

In fact, foreign fighters have done more than participate in terrorist attacks in their countries of origin. While much has been written about the motivations of foreign fighters and their activities on the battlefields of Syria and Iraq, less research has focused on the foreign volunteers in the provinces or elsewhere. ${ }^{30}$ The following paragraphs provide a brief summary of these roles, as well as specific examples from the current and past conflicts. That said, much more research is needed in this area.

External Operatives. The most obvious role played by foreign fighters and foreign fighter returnees is that of operative. As mentioned previously, seven of the nine perpetrators of the 2015 Paris attacks were foreign fighter returnees. Other examples also exist. Mehdi Nemmouche, for example, was the first foreign fighter sent home from Syria to conduct an attack on the West. He was responsible for the May 2014 attack on the Jewish Museum in Brussels that killed four people. Additionally, in October 2015, Egyptian authorities sentenced to prison five members of an ISIS operational cell that allegedly had travelled from Libya to conduct an attack on the pyramids in Giza. One of these was an Egyptian returnee. The others came from Syria, Tajikistan, Belarus and Serbia. ${ }^{31}$

Logisticians. Another equally important, but often less understood role for foreign fighters is that of logistician. Multiple examples exist in the past and present. More recently, authorities have identified 30 individuals as having a direct role in the Paris 2015 attacks: nine perpetrators and 21 logisticians. ${ }^{32}$ Of the 21 logisticians, seven had previously fought in Syria and Iraq and, thus, were foreign fighter returnees. Similarly, in October 2002, Libyan Salem Saad Ben Suweid shot American diplomat Laurence Foley in Jordan. He had trained with Abu Musab al-Zarqawi in Afghanistan and subsequently joined "Tawhid wal-Jihad", the precursor to al-Qaeda in Iraq. Beyond this more direct operational role, Suweid was supported by other Afghanistan veterans, including individuals from Jordan, Kuwait and Syria. ${ }^{33}$

Recruiters. Foreign fighters also can be effective recruiters either via social media or in person. This type of recruitment goes beyond simply sending a message via Twitter that encourages homegrown terrorists to conduct attacks. Rather, recruiters develop a virtual or in-person relationship with prospective fighters and, subsequently, direct action. For example, Bahrun Naim is an Indonesian foreign fighter in Syria active on social media. He reportedly recruited 11 local Indonesian operatives, including three 
women, and then helped them plan a suicide attack on the Presidential Palace in Jakarta in December 2016. ${ }^{34}$ This plot was ultimately unsuccessful, but it demonstrates how foreign fighters can have an impact back home, even as they reside within a conflict zone. Similarly, over a decade ago, security forces arrested Egyptian recruiter Abu Jihad in Algiers in July 2005. He reportedly was identifying and assisting Algerian recruits as they attempted to travel to Iraq via Syria to fight for al-Qaeda. ${ }^{35}$

Leaders and Trainers. Finally, it is worth noting that, historically, some foreign fighters have joined other militant groups, train fighters, or even establish their own group upon their return home. Although much of the impact of ISIS foreign fighters has yet to be realized, multiple historical evidence exists that provides insight into this possibility. For example, approximately 4900 of the 7000 Algerians in Afghanistan between 1984 and 1993 eventually returned home; 90\% of them joined the Armed Islamic Group (GIA) and many assumed leadership positions. ${ }^{36}$ These individuals included Qari Sa'id, a well-known ideologue within the GIA, as well as Murad Si-Ahmad, its overall leader. ${ }^{37}$ Additionally, foreign fighters in Bosnia and Iraq helped establish training camps and provided local recruits with basic guerrilla warfare skills. ${ }^{38}$ In Iraq, Afghan veteran Usama al-Tunisi was responsible for training local recruits and other foreign fighters how to execute car bombings successfully. ${ }^{39}$

\section{Conclusion}

In conclusion, the global threat posed by ISIS provinces, affiliates and foreign fighters appears unlikely to diminish in the near term, despite successful operations in Mosul and Raqqah. ISIS provinces have already been able to establish an operational tempo that exceeds the historical precedent established by al-Qaeda. ISIS affiliates and cells outside these provinces similarly have sustained a campaign against not only security forces, but also civilian targets. Moreover, much of their success can be attributed to the effectiveness of ISIS foreign fighters. This effectiveness can be seen in their participation in external operations, but they also have been able to take on the role of logistician and recruiter. Finally, it seems likely that foreign fighters will follow historical patterns and attempt to provide local recruits with increased guerrilla warfare skills as well as establish new militant groups back home. 


\section{ENDNOTES}

1 O'Neill B. Insurgency and Terrorism: Inside Modern Revolutionary Warfare. - Washington DC: Brassey's, 1990. P. 24-27.

2 See, for example, Felter J., Fishman B. Al-Qaeda's Fighters in Iraq: A First Look at the Sinjar Records. - New York: West Point Academy, 2008; Perlinger A., Milton D. From Cradle to Grave: The Lifecycle of Foreign Fighters in Syria and Iraq. - New York: West Point Academy, 2016.

3 See, for example, Bergen P., Shuster C., Sterman D. ISIS in the West: The New Faces of Extremism. - Washington DC: New America Foundation, 2015.

4 These papers include the following: Cragin K. The challenge of foreign fighter returnees // Journal of Contemporary Criminal Justice (forthcoming in July 2017); Cragin K. The November 2015 Paris attacks: The impact of foreign fighter returnees // Orbis. 2017. V. 61. № 2. P. 212-226.

${ }^{5}$ Naji A.B. Management of Savagery: The Most Critical State Through Which the Ummah will Pass. Transl. by W.McCants. Unpublished manuscript. 2004. Available online at URL: <https://azelin.files. wordpress.com/2010/08/abu-bakr-naji-the-management-of-savagery-the-most-critical-stage-throughwhich-the-umma-will-pass.pdf>, last accessed 12 January 2017.

6 Al-Adnani A.M. This is the Promise of Allah. Statement released by al-Hayat Media Center. 30 June 2014.

${ }^{7}$ A Call to Hijrah // Dabiq. No. 3. 14 May 2015.

8 Author interviews with Hizb ut-Tahrir. London, March 2004; author interviews with Justice Party. Jakarta, March 2006; see also Cragin K. Al-Qa'ida confronts Hamas: divisions in the Sunni-Jihadist movement and its implications for US Policy // Studies in Conflict and Terrorism. 2009. V. 32. № 7. P. 576-590.

${ }^{9}$ For further information, see Kepel G. Jihad: The Trail of Political Islam. - London: I.B. Tauris, 2002; Gerges F.A. The Far Enemy: Why Jihad Went Global. - New York: Cambridge University Press, 2005.

${ }^{10}$ Azzam A. Defense of Muslim Lands. Unpublished manuscript, 1984.

11 Al-Zawahiri A. Bitter Harvest: The Muslim Brotherhood in 60 Years. Transl. by N.Masid. Unpublished manuscript, 1991.

12 Author interviews with security official. Jordan, February 2017.

${ }^{13}$ Gerges F.A. Op. cit.

${ }^{14}$ Zackie Masoud M.W. An analysis of Abu Musa'b al-Suri's call to global Islamic resistance // Journal of Strategic Studies. 2013. V. 6. № 1. P. 1-18; Naji A.B. Op. cit.

${ }^{15}$ Brynjar L. Architect of Global Jihad: The Life of al-Qa'ida Strategist Abu Mus'ab al-Suri. - New York: Columbia University Press, 2008. P. 380-381.

16 Ibid. P. 409. ISIS clearly has rejected this view: see the English-language publication by ISIL entitled The Murthad Brotherhood // Dabiq. No. 14. 13 April 2016. P. 30-32. 
17 Naji A.B. Op. cit. P. 77-78.

${ }^{18}$ Al-Adnani A.M. Op. cit.

19 For further information, see URL: <https://www.trackingterrorism.org/chatter/trac-insight-listislamic-state-wilayats-alt-wilayah-nation>, last accessed 7 March 2017.

20 Egypt police kill leading Islamic State militant in Cairo // al-Arabi al-Jadeed. 9 November 2015.

21 For further discussion, see Watts C. One year later, ISIS overtakes al-Qaeda: what's next? // Foreign Policy Research Institute Blog. 8 April 2015. URL: <http://www.fpri.org/2015/04/one-yearlater-isis-overtakes-al-qaeda-whats-next/>, last accessed 8 March 2017.

22 This number comes from the Global Terrorism Database, hosted by START, at the University of Maryland. URL: <http://www.start.umd.edu/gtd/>. To arrive at this number, we searched for attacks by al-Qaeda affiliates ("Abu Sayyaf" Group, al-Qaeda, al-Qaeda in Iraq, al-Qaeda in the Arabian Peninsula, al-Qaeda in the Islamic Maghreb, "Jemaah Islamiyyah", "al-Shabaab" and al-Qaeda in Yemen). We also removed "uncertain" attacks or attacks that might not be driven by political objectives. But we allowed for insurgent-like attacks in the search criteria, as this allowed for a more appropriate comparison with ISIS attacks.

${ }^{23} \mathrm{Al}$-Shabaab joining al-Qaeda, monitor group says // CNN Wire. 10 February 2012.

24 This period was chosen because it represents the height of al-Qaeda attacks worldwide and occurred prior to the death of Osama bin Laden, al-Qaeda's founder and first leader.

25 De Young K. Papers paint new Portrait of Iraq's foreign Insurgents // The Washington Post. 21 January 2008.

26 Figures vary somewhat. These estimates were taken from the not-for-profit "Iraq Body Count" website, which utilizes public sources. URL: <https://www.iraqbodycount.org/analysis/numbers/ 2007>, last accessed 20 December 2016.

${ }^{27}$ For further information on foreign fighters in Syria and Iraq, see reports issued by the International Center for the Study of Radicalization and Political Violence, a research center located in King's College, London. URL: <http://icsr.info/category/publications/>.

28 How a secretive branch of ISIS built a global network of killers // Asharq al-Awasat. 5 August 2016; Chulov M. How ISIS laid out its plans to export chaos to Europe // The Guardian. 25 March 2016.

29 In January 2016, ISIL released the names of the operatives in a video entitled: Kill Them All Wherever you Find Them. Al-Hayat Media Center, 24 January 2016; see also Callimachi R. ISIS video appears to show Paris assailants earlier in Syria and Iraq // New York Times. 25 January 2016; Cragin K. The November 2015 Paris Attacks. Op. cit.

30 See, for example, Harkin J. Hunting Season: James Foley, ISIS and the Kidnapping Campaign that Started a War. - New York: Hachette Books, 2015; Felter J., Fishman B. Op. cit.; Perlinger A., Milton D. Op. cit.; Vidino L., Hughes S. ISIS in America: From Retweets to Raqqa. Washington D.C.: George Washington University, 2015. 
31 Al-'Alim W.A. Fall of the dangerous Daesh cell that was plotting to commit subversive attacks and undermine the economy // al-Ahram Online. 26 October 2015.

32 Belgian Foreign Minister Reynders cited in "Suspect Salah Abdeslam planned further attacks // BBC News. 20 March 2016; Cragin K. The November 2015 Paris attacks. Op. cit.

33 Brisard J.-C. Zarqawi: The New Face of al-Qaeda. - New York: Other Press, 2005. P. 83-86.

${ }^{34}$ Campbell C. ISIS unveiled: The story behind Indonesia's first female suicide bomber // Time Magazine. 3 March 2017.

35 Muqaddam M. Algeria: Egyptian recruiting fighters for al-Zarqawi's group arrested // al-Hayah. 2 July 2005.

${ }^{36}$ Cragin $\mathrm{K}$. The challenge of foreign fighter returnees. Op. cit.

${ }^{37} \mathrm{Ibid}$. See also Filiu J.-P. The local and the global Jihad of al-Qa'ida in the Islamic Maghrib // The Middle East Journal. 2009. V. 63. № 2. P. 213-226.

38 International Tribunal for the Prosecution of Persons Responsible for Serious Violations of International Humanitarian Law Committed in the Territory of the Former Yugoslavia since 1991. The Prosecutor v. Enver Hadzihasanovic and Amir Kubura. 15 March 2006. URL: <http://www.icty.org/ x/cases/hadzihasanovic_kubura/tjug/en/had-judg060315e.pdf>, last accessed 22 December 2016.

39 Tyson A.S. U.S. kills a leader of Al-Qaeda in Iraq; Tunisian directed foreign fighters // The Washington Post, 29 September 2007. 